\title{
Deciphering the Risk Factors of Autism: Are We There Yet?
}

\author{
Rasheeba Nizam, Suad Al Fadhli* \\ Department of Medical Laboratory Sciences, Faculty of Allied Health Sciences, Kuwait University, Kuwait City, Kuwait \\ Email: ^s.alfadhli@hsc.edu.kw, *suadq8@yahoo.com
}

How to cite this paper: Nizam, R. and Al Fadhli, S. (2016) Deciphering the Risk Factors of Autism: Are We There Yet? Journa of Biosciences and Medicines, 4, 65-76. http://dx.doi.org/10.4236/jbm.2016.410007

Received: June 27, 2016

Accepted: October 18, 2016

Published: October 21, 2016

Copyright (c) 2016 by authors and Scientific Research Publishing Inc. This work is licensed under the Creative Commons Attribution International License (CC BY 4.0).

http://creativecommons.org/licenses/by/4.0/ (c) (i) Open Access

\section{Abstract}

Background: Autism represents a group of developmental disorder that pose a major challenge to world-wide societies and healthcare providers with limited diagnostics and medical cure. It is widely been considered as a mental disorder characterized by speech deficit and repetitive behavior. The presumed etiology of autism involves genetic, immunologic, intestinal and synaptic irregularities, aside from environmental toxicities. Yet, the prospective factor that triggers or predominates autism remains barely understood. Objective: Herein we aim to review the literature to identify the risk factors associated with the development of autism and the need to investigate the underlying pathological events. Results: Genetic factors have been widely investigated in autism for its role in inflammation, neuronal function, metabolism and detoxification. It's assumed to be negatively impacted by heavy metals, allergens, infectious agents and environmental pollutants. Considering the fact that, these elements individually does not make up autism, one would expect a complex interplay of neuro inflammatory and gastrointestinal system in the pathophysiology of the disease. Gut-brain axis may serve as a potential pathological link representing the plethora of mechanistic events involved in the development of autism. Abnormal activation of mast and neuro glial cells may lead to deregulated expression of cytokines and neuroactive compounds, which may disrupt the blood brain barrier permeability leading to inflammation. Alternatively it may also interfere with intestinal permeability, gut physiology, microbial composition and related metabolites. Conclusion: A glance through the literature indicates the likelihood of genetic variations and environmental factors in triggering a cascade of inflammatory events leading to the development of autism. Though relatively little information is known regarding the factors that initiate the onset and the progression of the disease; the rising prevalence of autism across the globe alarms us towards a better know-how of the disease and the shortfalls in disease treatment and management. 


\section{Keywords}

Autism, Risk, Gut-Brain Axis

\section{Introduction}

Autism spectrum disorder (ASD [MIM 209850]) includes a group of complex developmental disorders characterized by difficulties in social interaction, verbal and nonverbal communication and repetitive behaviors. It affects $1 \%$ world population with wide range of behavioral and clinical heterogeneity that leads to substantial challenges in their diagnosis [1] [2]. Autism is found to be four times more common in males than females [3] [4]. Its outpacing prevalence across different geographical locations alarms us towards a better know-how of disease. The exact cause/triggers of autism remains unknown with multiple genetic, immunological and environmental factors contributing to the disease (Figure 1).

\section{Genetics of Autism}

Increasingly, genetic predisposition and immune reactions are presumed to be the key

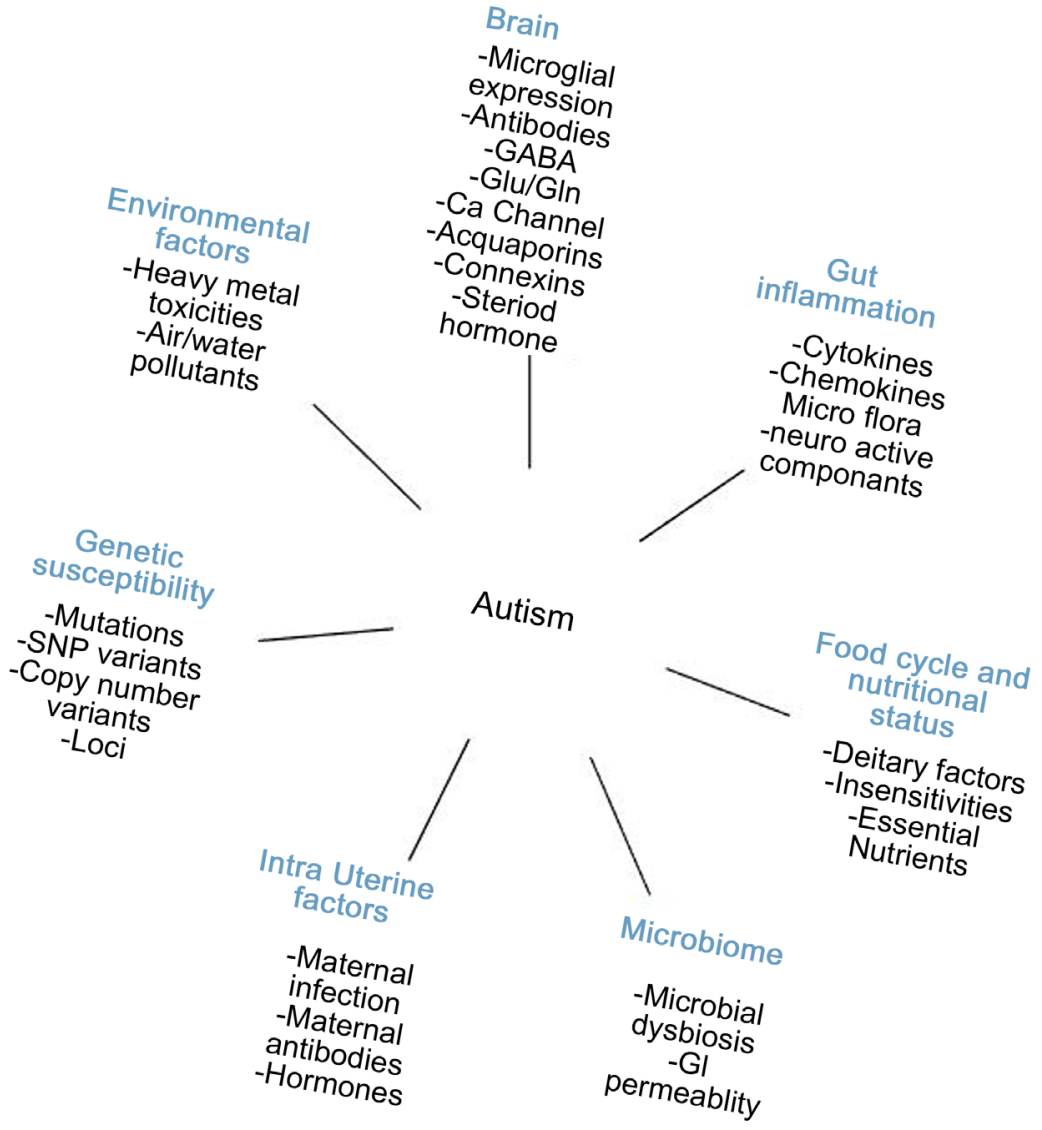

Figure 1. Represents core elements that tend to influence the onset of Autism. 
players of autism. Twin studies and family studies have shown a strong genetic contribution to their etiology with $82 \%-92 \%$ concordance in monozygotic twins and $1 \%-$ $10 \%$ in dizygotic twins [3] [4]. Genome wide linkage, association, sequencing and copynumber variant studies have led to the identification of multiple variant's that can predispose to autism, presented in Figure 2 [5]-[10]. Multiple loci have been identified to be responsible for autism and these include chromosome 1q31.1, 1p13.2, 2q31, 3q, 5p13, 7q (22, 34), 8q24, 13q, 16p, 17q, 15q, 19p and Xq [11] [12]. A broad variety of mutations responsible for autism have been discovered in recent years, including the mutant forms of NRXN1, CNTN4, NLGNs and SHANK3 [5]. Vastly, these mutations are presumed to be involved in neuronal development, synaptic functions, ion channel and transmembrane activity. Literature data indicates that majority of these genes are inter-related and may influence the function of each other indicating a complex network of deregulated genes in autism (Figure 2). However, increasing incidence of autism (1in 68, Centers for Disease Control, 2014) and their heterogeneous behavioral and clinical spectrum direct towards the role of additional factors in the pathogenesis of disease. The theory of rare variants and common complex diseases also gains attention in autism due to larger effect size and associated clinical heterogeneity. Understanding the exact model of genetic architecture entails further intensive research.

\section{Gut-Brain Axis: An Inflammatory Dialoguein Autism}

Gut-brain inflammation has been regarded as one of the most intriguing causes of autism. The enteric nervous system (ENS), recently been considered as the second brain, is embedded in the gastrointestinal system with multiple neurons organized into two layers of gut tissues known as myenteric and submucosal plexus; comprising ofimmune cells and neurotransmitters such as serotonin, dopamine, glutamate, norepinephrine and nitric oxide, aside from glial cells, neuropeptides and psychoactive compounds. Apart from its evident role in persuading emotional outcomes such as stress, fear or excitement; ENStends tobe involved inmast cell mediated allergic and/or host immune response.

An imbalance in Th1 and Th2 like cytokines and an increase in circulating autoantibodies to neuron-axon filament protein and glial fibrillary acidic protein indicates a series of selective immune regulatory events in the development of autism [13] [14]. One of the hypothesis of autism development postulates that hyper-activation of mast cells results in increased secretion of inflammatory cytokines and histamine [15] leading to leaky gut and apparently brain inflammation. Supportively, increased levels of IL-6 and TNF have been reported in brain and cerebro spinal fluid of autistic patients respectively [16] [17]. Reduced plasma levels of TGF-b in ASD [18], probably accounts for increased mast cell activation and reduced T-cell regulatory functions. High histamine levels are often observed in males as is the prevalence of autism. As a neurotransmitter, increased production of histamines tends to have deleterious effect on brain causing mood swings, hyper activity, compulsive behavior, anxiety, lack of appetite, loss of memory and frequent crying, which are predominantly observed in autistic children. 


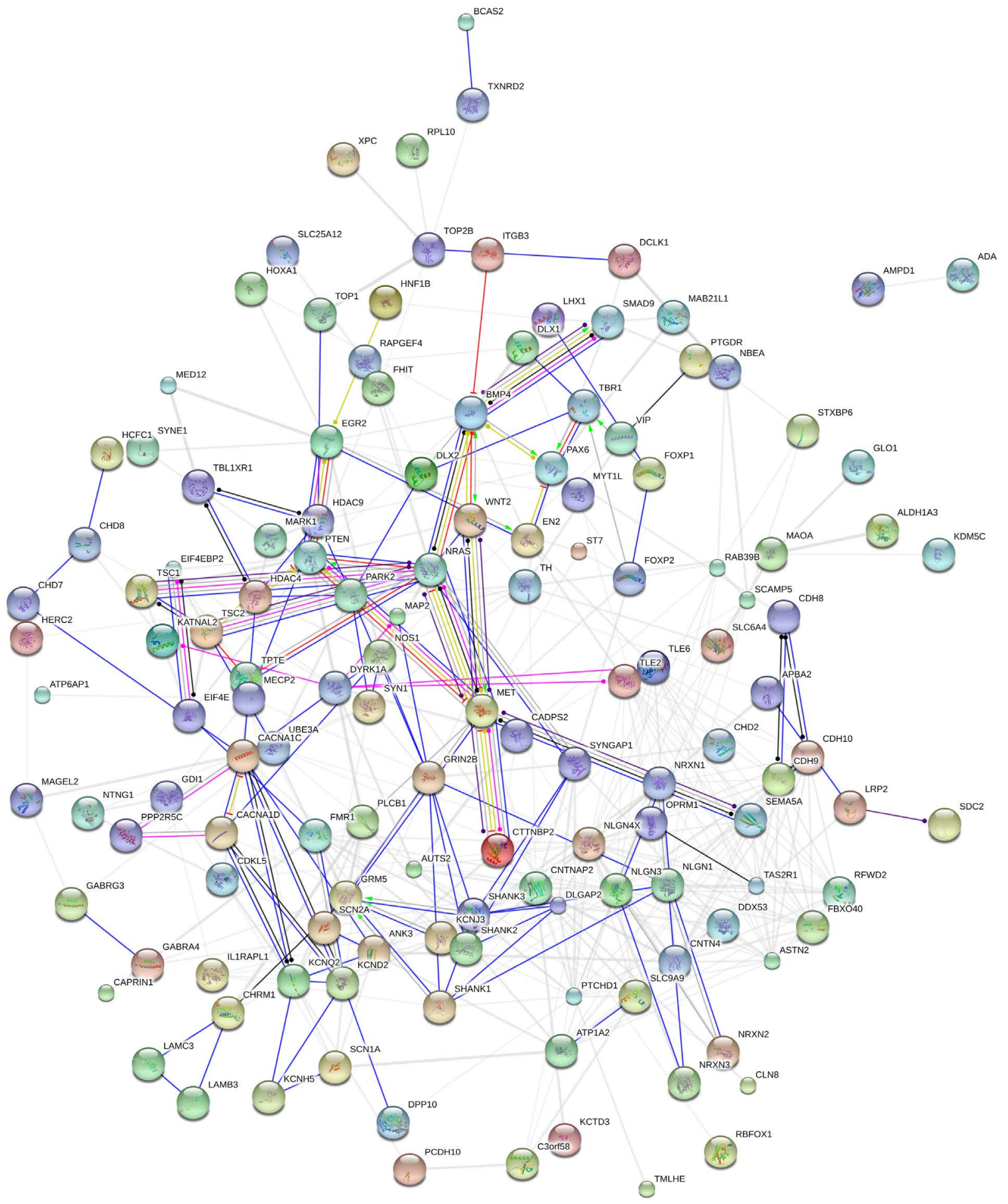

Figure 2. Protein network of the predicted genes from the literature presumed to be associated with autism development. The network nodes are proteins and the edges represent the predicted functional associations. Differently colored lines, represent their mode of action. A blue line indicates-Binding; a violet line-Catalysis; a pink line-Post translational modification; and a yellow line-Expression. Arrow at the end of the edge next indicates the directionality of the action. Red bar indicates down-regulation and green arrow indicates up-regulation. The circle indicates that the directionality of the interaction is known, but the end result is unknown. 
One of the consequences of perinatal mast cell activation includes gut-blood brain barrier (BBB) disruption permitting the neurotoxic molecules to enter brain causing inflammation. BBB permeability tends to be tightly regulated by the contribution of cerebral endothelial cells, pericytes and glial cells [19]. Among the endothelial cells, tight junctions are most important components of $\mathrm{BBB}$; significantly altered expression of MMP9 in autistic subject's [20] possibly directs towards MMP2/MMP9 mediated disruption of tight junctions [21]. MCP1 is a chemoattractant for mast cells that has shown to be elevated in cerebro spinal fluid and microglia of autism patients [22], and may further contribute to vasodilation. Neurotensin is yet another protein that tend to stimulate the mast cells and exert neuro-modulatory functions [23]. Microglial neurotensin stimulates glial cell proliferation; abnormal microglial growth and activation have been reported to be central inautism development [24] [25]. It also tends to facilitate seizures through activation of glutamate receptors [26]. Glutamate is the most abundant aminoacid present in the CNS and gut. Recently increased plasma levels of glutamate and decreased levels of glutamine has been reported in high-functioning autistic children compared to controls [26]. Post mortem studies have also implicated abnormalities in the expression of glutamate receptors and transporter system in the brain tissues of autistic subjects [27]. Relative changes in the measure of glutamate and/or GABA have been proposed to affect the excitation/inhibition equilibrium of cortical networks, interfering with neural communication, memory formation and learning [28]. Dysregulation of other neuropeptides such as oxytocin and vasopressin also gains attention in autismdue to its influential role in behavior and social interaction [29]. The impact of environmental, nutritional and microbial flora may further depict the inflammatory role of gut-brain axis in the development of autism.

\section{Environmental Causes of Autism}

Existing data also suggests the significance of dietary and environmental exposure to heavy metals in autsim development [19]. Marked up increase in the level of mercury, lead and aluminum in the autistic children, radically indicates its impact on neural functions [30]. These heavy metals are likely to disturb calcium channel activity and may negatively impact endothelial cells and astrocytes [31]. Calcium essentiallyplays a key role in the expression of aquaporin's and connexins that tend to regulate cerebral blood flow. Remarkably, deregulated expression of aquaporin's and connexins have been implicated in autism [32]. Genes involved in heavy metal detoxification such as PON1 and GST have also been linked to autism development [33] [34]. Safety of vaccines has also been much on debate with an unsubstantiated link between MMR and autism development. It has been speculated that toxicological contribution of vaccine components and simultaneous administration of multiple vaccines devastates/weakens the immune system and creates an interaction with the nervous system triggering autism in genetically susceptible individual. Living in areas with higher levels of styrene and chromium and exposure to dioxins during pregnancy have also been associated with the risk of autism [35]. 


\section{Food Cycle and Nutritional Status in Autism}

Dietary factors can cause varying degree of inflammation influencing the disease risk and severity. Increased sugar uptake, processed food and low nutrient diet are some of the factors contributing to the inflammation cycle. Food allergies are more prevalent in children with autism than those without, including the picky eating habits and food aversions [36]. Food that contain or tend to release histamine upon ingestion includes fermented food products, wheat, milk, soy etc. There are reported cases of children with autism who showed notable decline in symptoms when placed on gluten-free and/or casein-free diets, though not scientifically proven yet. The decreased absorption/ deficiency of essential nutrients such as omega-3 fats, vitamin A, B1, B6, B12, C, D, zinc and magnesium, through the intestinal tract could also lead to inflammation. Deficiency of essential amino acids such as tyrosine and tryptophan have also been raised as a concern, given their role as neurotransmitter [37]. Low Vitamin D status has been recently associated with autism [38] suggesting deficit in brain and gut function. There are multiple reports indicating improvement in core symptoms of autism on Vitamin D supplementation [38]. Similarly, low vitamin B12 status has also been speculated with autism onset for its role in myelin sheath formation.

\section{Microbiome and Autism}

Selective animal model and human studies also indicate that disturbances in intestinal microflora may have an over-riding influence on the bidirectional communication between the gut-brain axis, instigating gastrointestinal and neurobehavioral issues [39]. Variations in gut microbiome have been linked to autism with clostridia growth rate being a key risk factor. It has been speculated that the relative balances between the inflammatory microbes such as clostridia and desulfovibrio, and the anti-inflammatory microbe bifidobacteria may become destabilized prior to autism development [40] [41]. Certain enteric metabolite such as p-cresol, enteric short-chain fatty acids such as propionic acid derived from clostridia species have been reported to be elevated in autistic children [42]. The overload of these components could also be of environmental origin due to its role as disinfectant and preservative agents [43] [44]. Bacterial over load, dietary factors and accumulative environmental toxins may collectively contribute to the gastrointestinal (GI) permeability associated with autism.

\section{Intra Uterine Factors}

Maternal viral infection in the first semester and bacterial infection in the second semester have been associated with the risk of autism development in the offspring [45]. Hormonal imbalance during pregnancy could also contribute to the development of autism. Increased steroid hormones such as progesterone, $17 \alpha$-hydroxy-progesterone, androstenedione and testosterone in autistic subjects stipulates the influence of steroidogenic activity on early fetal brain development [46]. High level of testosterone coupled with reduced expression of estrogen receptor beta, estrogen co-activators and aromatase; an enzyme that converts testosterone to estrogen [46] [47], possibly clues 
the gender bias observed in autism. Given its critical role in the development of cholinergic and dopaminergic neurons, deficiency of thyroid hormones could also contribute to the behavioral and cognitive deficits observed in autism.

\section{Conclusion}

Autism in a nutshell signifies beyond a mere state of communication deficit. It indicates a complex series of neuro inflammatory-gastrointestinal events subsequent of immune dysfunction. Genetic predisposition is considered to be a key factor contributing to the disease; a comprehensive understanding of gene-gene network and gene-environment interactions may provide valuable tool to explain the clinical outcomes and severity of disease. Given the complex interaction between genetic, environmental, neuronal, immunologic, nutritional, microbial and intra uterine factors, the root cause that initiates/ triggers the disease remains largely unknown. Gut-brain axis could be a potential target to unravel the root cause of the disease. An intensive research with respect to specific risk factors would enable early interventions, increasing the momentum of hope to cure the disease.

\section{Looking Forward}

The rising autism rates and the lack of well-defined medical treatment regime represents a major challenge to the medical sector. Despite the remarkable increase in the number of causative factors associated with autism, the need for the assessment of underlying medical comorbidities appears to be largely overlooked by the current system. Though intense speech /language/ occupational therapy would improve the associated behavioral and social issues; the underlying pathological condition requires a more intense treatment plan. There is an intimidate need for laboratory/clinical profiling for the efficient management of the disease, if not the diagnosis. A general screening for the deficiency of essential nutrients, food hypersensitivity, urine and stool comprehensive analysis for the presence of bacteria/fungal overload, aminogram for inborn errors of metabolism, heavy metal screening and hormonal imbalance, may to some extent address the related complications and comorbidities. A professionally supported integrative holistic approach involvingclinical and psychological interventions, alongside life style modifications such as customized diet plan, nutritional \& probiotic supplementation and regular detoxification protocols mayenormously benefit the disease treatment and management policy.

\section{Conflict of Interest}

None declared.

\section{References}

[1] Steinberg, J. and Webber, C. (2013) The Roles of FMRP-Regulated Genes in Autism Spectrum Disorder: Single- and Multiple-Hit Genetic Etiologies. The American Journal of Human Genetics, 93, 825-839. http://dx.doi.org/10.1016/j.ajhg.2013.09.013 
[2] Volkmar, F.R., State, M. and Klin, A. (2009) Autism and Autism Spectrum Disorders: Diagnostic Issues for the Coming Decade. Journal of Child Psychology and Psychiatry, 50, 108-115. http://dx.doi.org/10.1111/j.1469-7610.2008.02010.x

[3] Freitag, C.M. (2007) The Genetics of Autistic Disorders and Its Clinical Relevance: A Review of the Literature. Molecular Psychiatry, 12, 2-22.

http://dx.doi.org/10.1038/sj.mp.4001896

[4] Abrahams, B.S. and Geschwind, D.H. (2008) Advances in Autism Genetics: On the Threshold of a New Neurobiology. Nature Reviews Genetics, 9, 341-355.

http://dx.doi.org/10.1038/nrg2346

[5] Xia, K., Guo, H., Hu, Z., Xun, G., Zuo, L., Peng, Y., Wang, K., He, Y., Xiong, Z., Sun, L., Pan, Q., Long, Z., Zou, X., Li, X., Li, W., Xu, X., Lu, L., Liu, Y., Hu, Y., Tian, D., Long, L., Ou, J., Liu, Y., Li, X., Zhang, L., Pan, Y., Chen, J., Peng, H., Liu, Q., Luo, X., Su, W., Wu, L., Liang, D., Dai, H., Yan, X., Feng, Y., Tang, B., Li, J., Miedzybrodzka, Z., Xia, J., Zhang, Z., Luo, X., Zhang, X., St Clair, D., Zhao, J. and Zhang, F. (2014) Common Genetic Variants on 1p13.2 Associate with Risk of Autism. Molecular Psychiatry, 19, 1212-1219.

http://dx.doi.org/10.1038/mp.2013.146

[6] Scheid, I., Maruani, A., Huguet, G., Leblond, C.S., Nygren, G., Anckarsäter, H., Beggiato, A., Rastam, M., Amsellem, F., Gillberg, I.C., Elmaleh, M., Leboyer, M., Gillberg, C., Betancur, C., Coleman, M., Hama, H., Cook, E.H., Bourgeron, T. and Delorme, R. (2013) Heterozygous FA2H Mutations in Autism Spectrum Disorders. BMC Medical Genetics, 14, 124. http://dx.doi.org/10.1186/1471-2350-14-124

[7] O’Roak, B.J., Deriziotis, P., Lee, C., Vives, L., Schwartz, J.J., Girirajan, S., Karakoc, E., Mackenzie, A.P., Ng, S.B., Baker, C., Rieder, M.J., Nickerson, D.A., Bernier, R., Fisher, S.E., Shendure, J. and Eichler, E.E. (2011) Exome Sequencing in Sporadic Autism Spectrum Disorders Identifies Severe de Novo Mutations. Nature Genetics, 43, 585-589.

http://dx.doi.org/10.1038/ng.835

[8] Jiang, Y.H., Yuen, R.K., Jin, X., Wang, M., Chen, N., Wu, X., Ju, J., Mei, J., Shi, Y., He, M., Wang, G., Liang, J., Wang, Z., Cao, D., Carter, M.T., Chrysler, C., Drmic, I.E., Howe, J.L., Lau, L., Marshall, C.R., Merico, D., Nalpathamkalam, T., Thiruvahindrapuram, B., Thompson, A., Uddin, M., Walker, S., Luo, J., Anagnostou, E., Zwaigenbaum, L., Ring, R.H., Wang, J., Lajonchere, C., Wang, J., Shih, A., Szatmari, P., Yang, H., Dawson, G., Li, Y. and Scherer, S.W. (2013) Detection of Clinically Relevant Genetic Variants in Autism Spectrum Disorder by Whole-Genome Sequencing. The American Journal of Human Genetics, 93, 249-263. http://dx.doi.org/10.1016/j.ajhg.2013.06.012

[9] Levy, D., Ronemus, M., Yamrom, B., Lee, Y.H., Leotta, A., Kendall, J., Marks, S., Lakshmi, B., Pai, D., Ye, K., Buja, A., Krieger, A., Yoon, S., Troge, J., Rodgers, L., Iossifov, I. and Wigler, M. (2011) Rare de Novo and Transmitted Copy-Number Variation in Autistic Spectrum Disorders. Neuron, 70, 886-897. http://dx.doi.org/10.1016/j.neuron.2011.05.015

[10] Sebat, J., Lakshmi, B., Malhotra, D., Troge, J., Lese-Martin, C., Walsh, T., Yamrom, B., Yoon, S., Krasnitz, A., Kendall, J., Leotta, A., Pai, D., Zhang, R., Lee, Y.H., Hicks, J., Spence, S.J., Lee, A.T., Puura, K., Lehtimäki, T., Ledbetter, D., Gregersen, P.K., Bregman, J., Sutcliffe, J.S., Jobanputra, V., Chung, W., Warburton, D., King, M.C., Skuse, D., Geschwind, D.H., Gilliam, T.C., Ye, K. and Wigler, M. (2007) Strong Association of de Novo Copy Number Mutations with Autism. Science, 316, 445-449. http://dx.doi.org/10.1126/science.1138659

[11] Gupta, A.R. and State, M.W. (2007) Recent Advances in the Genetics of Autism. Biological Psychiatry, 61, 429-437. http://dx.doi.org/10.1016/j.biopsych.2006.06.020

[12] Veenstra-Vanderweele, J., Christian, S.L. and Cook Jr., E.H. (2004) Autism as a Paradig- 
matic Complex Genetic Disorder. Annual Review of Genomics and Human Genetics, 5, 379-405. http://dx.doi.org/10.1146/annurev.genom.5.061903.180050

[13] Gupta, S., Aggarwal, S., Rashanravan, B. and Lee, T. (1998) Th1- and Th2-Like Cytokines in CD4+ and CD8+ T Cells in Autism. Journal of Neuroimmunology, 85, 106-109. http://dx.doi.org/10.1016/S0165-5728(98)00021-6

[14] Singh, V.K., Warren, R., Averett, R. and Ghaziuddin, M. (1997) Circulating Autoantibodies to Neuronal and Glial Filament Proteins in Autism. Pediatric Neurology, 17, 88-90. http://dx.doi.org/10.1016/S0887-8994(97)00045-3

[15] Theoharides, T.C., Angelidou, A., Alysandratos, K.D., Zhang, B., Asadi, S., Francis, K., Toniato, E. and Kalogeromitros, D. (2012) Mast Cell Activation and Autism. Biochimica et Biophysica Acta, 1822, 34-41. http://dx.doi.org/10.1016/j.bbadis.2010.12.017

[16] Wei, H., Zou, H., Sheikh, A.M., Malik, M., Dobkin, C., Ted Brown, W. and Li, X. (2011) IL-6 Is Increased in the Cerebellum of Autistic Brain and Alters Neural Cell Adhesion, Migration and Synaptic Formation. Journal of Neuroinflammation, 8, 52. http://dx.doi.org/10.1186/1742-2094-8-52

[17] Chez, M.G., Dowling, T., Patel, P.B., Khanna, P. and Kominsky, M. (2007) Elevation of Tumor Necrosis Factor-Alpha in Cerebrospinal Fluid of Autistic Children. Pediatric Neurology, 36, 361-365. http://dx.doi.org/10.1016/j.pediatrneurol.2007.01.012

[18] El Goharya, T.M., El Azizb, N.A., Darweeshc, M. and Sadaaa, E.S. (2015) Plasma Level of Transforming Growth Factor $\beta 1$ in Children with Autism Spectrum Disorder. Egyptian Journal of Ear, Nose, Throat and Allied Sciences, 16, 69-73. http://dx.doi.org/10.1016/j.ejenta.2014.12.002

[19] Kim, J.H., Byun, H.M., Chung, E.C., Chung, H.Y. and Bae, O.N. (2013) Loss of Integrity: Impairment of the Blood-Brain Barrier in Heavy Metal-Associated Ischemic Stroke. Toxicological Research, 29, 157-164. http://dx.doi.org/10.5487/tr.2013.29.3.157

[20] Abdallah, M.W., Pearce, B.D., Larsen, N., Greaves-Lord, K., Norgaard-Pedersen, B., Hougaard, D.M., Mortensen, E.L. and Grove, J. (2012) Amniotic Fluid MMP-9 and Neurotrophins in Autism Spectrum Disorders: An Exploratory Study. Autism Research, 5, 428-433. http://dx.doi.org/10.1002/aur.1254

[21] Ramos-Fernandez, M., Bellolio, M.F. and Stead, L.G. (2011) Matrix Metalloproteinase-9 as a Marker for Acute Ischemic Stroke: A Systematic Review. Journal of Stroke and Cerebrovascular Diseases, 20, 47-54. http://dx.doi.org/10.1016/j.jstrokecerebrovasdis.2009.10.008

[22] Abdallah, M.W., Larsen, N., Grove, J., Norgaard-Pedersen, B., Thorsen, P., Mortensen, E.L. and Hougaard, D.M. (2012) Amniotic Fluid Chemokines and Autism Spectrum Disorders: An Exploratory Study Utilizing a Danish Historic Birth Cohort. Brain Behavior and Immunity, 26, 170-176. http://dx.doi.org/10.1016/j.bbi.2011.09.003

[23] Ghanizadeh, A. (2010) Targeting Neurotensin as a Potential Novel Approach for the Treatment of Autism. Journal of Neuroinflammation, 7, 58. http://dx.doi.org/10.1186/1742-2094-7-58

[24] Morgan, J.T., Chana, G., Abramson, I., Semendeferi, K., Courchesne, E. and Everall, I.P. (2012) Abnormal Microglial-Neuronal Spatial Organization in the Dorsolateral Prefrontal Cortex in Autism. Brain Research, 1456, 72-81. http://dx.doi.org/10.1016/j.brainres.2012.03.036

[25] Rodriguez, J.I. and Kern, J.K. (2011) Evidence of Microglial Activation in Autism and Its Possible Role in Brain Underconnectivity. Neuron Glia Biology, 7, 205-213. http://dx.doi.org/10.1017/S1740925X12000142

[26] Ghanizadeh, A. (2013) Increased Glutamate and Homocysteine and Decreased Glutamine 
Levels in Autism: A Review and Strategies for Future Studies of Amino Acids in Autism. Disease Markers, 35, 281-286. http://dx.doi.org/10.1155/2013/536521

[27] Purcell, A.E., Jeon, O.H., Zimmerman, A.W., Blue, M.E. and Pevsner, J. (2001) Postmortem Brain Abnormalities of the Glutamate Neurotransmitter System in Autism. Neurology, 57, 1618-1628. http://dx.doi.org/10.1212/WNL.57.9.1618

[28] Harada, M., Taki, M.M., Nose, A., Kubo, H., Mori, K., Nishitani, H. and Matsuda, T. (2011) Non-Invasive Evaluation of the GABAergic/Glutamatergic System in Autistic Patients Observed by MEGA-Editing Proton MR Spectroscopy Using a Clinical 3 Tesla Instrument. Journal of Autism and Developmental Disorders, 41, 447-454. http://dx.doi.org/10.1007/s10803-010-1065-0

[29] Miller, M., Bales, K.L., Taylor, S.L., Yoon, J., Hostetler, C.M., Carter, C.S. and Solomon, M. (2013) Oxytocin and Vasopressin in Children and Adolescents with Autism Spectrum Disorders: Sex Differences and Associations with Symptoms. Autism Research, 6, 91-102. http://dx.doi.org/10.1002/aur.1270

[30] Mohamed Fel, B., Zaky, E.A., El-Sayed, A.B., Elhossieny, R.M., Zahra, S.S., Salah Eldin, W., Youssef, W.Y., Khaled, R.A. and Youssef, A.M. (2015) Assessment of Hair Aluminum, Lead, and Mercury in a Sample of Autistic Egyptian Children: Environmental Risk Factors of Heavy Metals in Autism. Behavioural Neurology, 2015, Article ID: 545674. http://dx.doi.org/10.1155/2015/545674

[31] Matter, K. and Balda, M.S. (2015) Signalling to and From Tight Junctions. Nature Reviews Molecular Cell Biology, 4, 225-236. http://dx.doi.org/10.1038/nrm1055

[32] Fatemi, S.H., Folsom, T.D., Reutiman, T.J. and Lee, S. (2008) Expression of Astrocytic Markers Aquaporin 4 and Connexin 43 Is Altered in Brains of Subjects with Autism. Synapse, 62, 501-507. http://dx.doi.org/10.1002/syn.20519

[33] Tian, Y., Green, P.G., Stamova, B., Hertz-Picciotto, I., Pessah, I.N., Hansen, R., Yang, X., Gregg, J.P., Ashwood, P., Jickling, G., Van de Water, J. and Sharp, F.R. (2011) Correlations between Gene Expression and Mercury Levels in Blood of Boys with and without Autism. Neurotoxicity Research, 19, 31-48. http://dx.doi.org/10.1007/s12640-009-9126-x

[34] Tian, Y., Green, P.G., Stamova, B., Hertz-Picciotto, I., Pessah, I.N., Hansen, R., Yang, X., Gregg, J.P., Ashwood, P., Jickling, G., Van de Water, J. and Sharp, F.R. (2011) Correlations of Gene Expression with Blood Lead Levels in Children with Autism Compared to Typically Developing Controls. Neurotoxicity Research, 19, 1-13. http://dx.doi.org/10.1007/s12640-009-9126-x

[35] Talbott, E.O., Marshall, L.P., Rager, J.R., Arena, V.C., Sharma, R.K. and Stacy, S.L. (2015) Air Toxics and the Risk of Autism Spectrum Disorder: The Results of a Population Based Case-Control Study in Southwestern Pennsylvania. Environmental Health, 14, 80. http://dx.doi.org/10.1186/s12940-015-0064-1

[36] Williams, P.G., Dalrymple, N. and Neal, J. (2000) Eating Habits of Children with Autism. Pediatric Nursing, 26, 259-264.

[37] Arnold, G.L., Hyman, S.L., Mooney, R.A. and Kirby, R.S. (2003) Plasma Amino Acids Profiles in Children with Autism: Potential Risk of Nutritional Deficiencies. Journal of Autism and Developmental Disorders, 33, 449-454. http://dx.doi.org/10.1023/A:1025071014191

[38] Wang, T., Shan, L., Du, L., Feng, J., Xu, Z., Staal, W.G. and Jia, F. (2015) Serum Concentration of 25-Hydroxyvitamin D in Autism Spectrum Disorder: A Systematic Review and Meta-Analysis. European Child \& Adolescent Psychiatry, 25, 341-350. http://dx.doi.org/10.1007/s00787-015-0786-1

[39] Rosenfeld, C.S. (2015) Microbiome Disturbances and Autism Spectrum Disorders. Drug Metabolism and Disposition, 43, 1557-1571. http://dx.doi.org/10.1124/dmd.115.063826 
[40] Weston, B., Fogal, B., Cook, D. and Dhurjati, P. (2015) An Agent-Based Modeling Framework for Evaluating Hypotheses on Risks for Developing Autism: Effects of the Gut Microbial Environment. Medical Hypotheses, 84, 395-401. http://dx.doi.org/10.1016/j.mehy.2015.01.027

[41] Tomova, A., Husarova, V., Lakatosova, S., Bakos, J., Vlkova, B., Babinska, K. and Ostatnikova, D. (2015) Gastrointestinal Microbiota in Children with Autism in Slovakia. Physiology \& Behavior, 138, 179-187. http://dx.doi.org/10.1016/j.physbeh.2014.10.033

[42] Gabriele, S., Sacco, R., Altieri, L., Neri, C., Urbani, A., Bravaccio, C., Riccio, M.P., Iovene, M.R., Bombace, F., De Magistris, L. and Persico, A.M. (2016) Slow Intestinal Transit Contributes to Elevate Urinary P-Cresol Level in Italian Autistic Children. Autism Research, 9, 752-759. http://dx.doi.org/10.1002/aur.1571

[43] Zarate, G., Gonzalez, S. and Chaia, A.P. (2004) Assessing Survival of Dairy Propionibacteria in Gastrointestinal Conditions and Adherence to Intestinal Epithelia. Methods in Molecular Biology, 268, 423-432. http://dx.doi.org/10.1385/1-59259-766-1:423

[44] Agency for Toxic Substances and Disease Registry (ATSDR) (1990) Toxicological Profile for Cresols. Public Health Service, US Department of Health and Human Services, Atlanta.

[45] Atladóttir, H.O., Thorsen, P., Ostergaard, L., Schendel, D.E., Lemcke, S., Abdallah, M. and Parner, E.T. (2010) Maternal Infection Requiring Hospitalization during Pregnancy and Autism Spectrum Disorders. Journal of Autism and Developmental Disorders, 40, 14231430. http://dx.doi.org/10.1007/s10803-010-1006-y

[46] Baron-Cohen, S., Auyeung, B., Norgaard-Pedersen, B., Hougaard, D.M., Abdallah, M.W., Melgaard, L., Cohen, A.S., Chakrabarti, B., Ruta, L. and Lombardo, M.V. (2015) Elevated Fetal Steroidogenic Activity in Autism. Molecular Psychiatry, 20, 369-376.

http://dx.doi.org/10.1038/mp.2014.48

[47] Crider, A., Thakkar, R., Ahmed, A.O. and Pillai, A. (2014) Dysregulation of Estrogen Receptor Beta (ER $\beta)$, Aromatase (CYP19A1), and ER Co-Activators in the Middle Frontal Gyrus of Autism Spectrum Disorder Subjects. Molecular Autism, 5, 46.

http://dx.doi.org/10.1186/2040-2392-5-46 


\section{Abbreviations}

ASD: Autism development disorder,

BBB: Blood brain barrier,

EEG: Electroencephalogram,

GABA: Gamma aminobutyric acid,

GST: Glutathione S-transferase,

IL: Interleukin,

MMP: Matrix metalloprotein,

MCP: Monocyte chemoattractant protein,

MMR: Measles, mumps, and rubella,

PON1: Paraoxonase 1,

Th: T-helper,

TGF-b: Transforming growth factor beta,

TNF: Tumor necrosis factor.

Submit or recommend next manuscript to SCIRP and we will provide best service for you:

Accepting pre-submission inquiries through Email, Facebook, LinkedIn, Twitter, etc.

A wide selection of journals (inclusive of 9 subjects, more than 200 journals)

Providing 24-hour high-quality service

User-friendly online submission system

Fair and swift peer-review system

Efficient typesetting and proofreading procedure

Display of the result of downloads and visits, as well as the number of cited articles

Maximum dissemination of your research work

Submit your manuscript at: http://papersubmission.scirp.org/

Or contact jbm@scirp.org 